\title{
EXONYMS AND OTHER GEOGRAPHICAL NAMES
}

Drago Perko, Peter Jordan, Blaž Komac

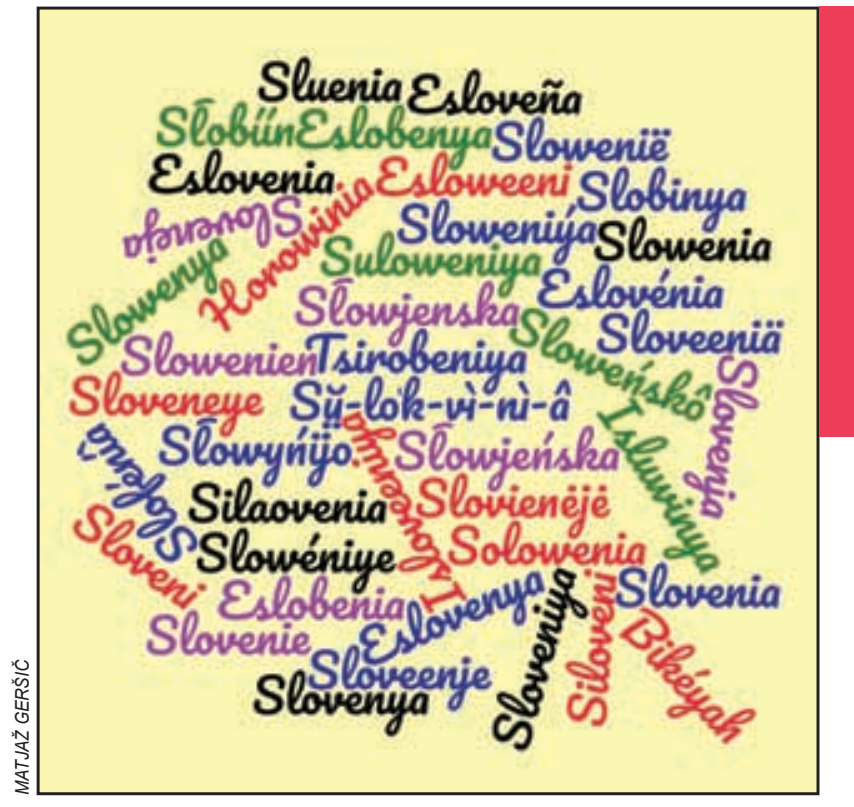

Slovenia as an exonym in some languages. 


\section{Exonyms and other geographical names}

DOI: http://dx.doi.org/10.3986/AGS.4891

UDC: $91: 81^{\prime} 373.21$

COBISS: 1.02

ABSTRACT: Geographical names are proper names of geographical features. They are characterized by different meanings, contexts, and history. Local names of geographical features (endonyms) may differ from the foreign names (exonyms) for the same feature. If a specific geographical name has been codified or in any other way established by an authority of the area where this name is located, this name is a standardized geographical name. In order to establish solid common ground, geographical names have been coordinated at a global level by the United Nations Group of Experts on Geographical Names (UNGEGN) since 1959. It is assisted by twenty-four regional linguistic/geographical divisions. Among these is the East Central and South-East Europe Division, with seventeen member states. Currently, the division is chaired by Slovenia. Some of the participants in the last session prepared four research articles for this special thematic issue of Acta geographica Slovenica. All of them are also briefly presented in the end of this article.

KEY WORDS: geographical name, endonym, exonym, UNGEGN, cultural heritage

This article was submitted for publication on November $15^{\text {th }}, 2016$.

\section{ADDRESSES:}

Drago Perko, Ph.D.

Anton Melik Geographical Institute

Research Center of the Slovenian Academy of Sciences and Arts

Novi trg 2, SI-1000 Ljubljana, Slovenia

E-mail: drago@zrc-sazu.si

Peter Jordan, Ph.D.

The Institute for Urban and Regional Research

Austrian Academy of Sciences

Postgasse 7/4/2, AT-1010 Vienna, Austria

E-mail: peter.jordan@oeaw.ac.at

Blaž Komac, Ph.D.

Anton Melik Geographical Institute

Research Center of the Slovenian Academy of Sciences and Arts

Novi trg 2, SI-1000 Ljubljana, Slovenia

E-mail:blaz.komac@zrc-sazu.si 


\section{Introduction}

Nouns are divided into common and proper nouns. In most languages, common nouns, such as river, mountain, and city, are not capitalized, whereas proper nouns (names), such as Danube, Mount Everest, and Ljubljana, are capitalized. Proper nouns also include geographical names.

A geographical name or toponym (from Greek tópos "place« and ónyma, a dialect variant of ónoma "name«) is a proper name of a geographical feature. The discipline dealing with geographical names is called toponymy. The entire body of geographical names in all the languages around the globe is divided into endonyms and exonyms, if geographical names are regarded under the aspect of the spatial relation between the community using the name and the geographical feature assigned by it. "Endonym « and »exonym " are status categories of geographical names. Depending on the spatial relationship between the user community and a feature, the same name can assume the status of an endonym or an exonym. Thus, the endonym/exonym divide results from a space-related or geographical view on place names.

An endonym (from Greek éndon »inside«) is a geographical name accepted and used by the local community. An exonym (from Greek éksō »outside «) is a geographical name used by an external community that is different from the endonym (Jordan 2016). Simply put, an endonym is the local (or original) name of a geographical feature and an exonym is a foreign name for the same feature (Kladnik 2009).

Thus, for example, Ljubljana is the Slovenian endonym and Laibach is the German exonym for the Slovenian capital city. In turn, Dunaj is the Slovenian exonym and Wien is the German endonym for the Austrian capital, Vienna, which is the English exonym. On the other hand, London is neither the Slovenian nor the German exonym for English London because, despite their different pronunciation, the Slovenian and German transcriptions of this geographical name are the same as in English.

The issue still remains how geographical names that are originally written in a different alphabetical, syllabic, or logographic script should be written in Roman script. Converting geographical names into Roman script is called Romanization (or sometimes Latinization). Here one distinguishes between transliteration and transcription (Kladnik and Perko 2013). In transliteration, the same character in the original script is always replaced with the same Roman character, often combined with a dot, line, tilde, or some other diacritic above or below the letter. In transcription, the sounds of the source language are rendered as faithfully as possible in the target language. This means that the phonetically transcribed forms of the same original geographical name may differ from one language to another. Thus, for example, the Russian river Печора is transcribed in Slovenian as Pečora, in German as Petschora, and in English as Pechora. In principle, it would be best to have an atlas of the world in which every name were written in both its original form and the form adapted to a given language, but unfortunately the lack of space on printed maps renders this impossible.

If a specific geographical name has been codified or in any other way established by an authority of the area where this name is located, this name is a standardized geographical name. Such names are usually presented in official gazetteers issued by an authority, such as the Geodetic Survey in Slovenia (Perko 2001).

\section{United Nations Group of Experts on Geographical Names}

At the global level, geographical names are overseen by the United Nations. In 1959, it founded the United Nations Group of Experts on Geographical Names (UNGEGN), which is one of the seven expert bodies of the United Nations Economic and Social Council (ECOSOC). Some of the main goals of UNGEGN are to encourage national and international geographical name standardization, to promote the international dissemination of nationally standardized geographical names, and to adopt individual Romanization systems. UNGEGN's goal for every country is to decide on its own nationally standardized names through the creation of national names authorities or recognized administrative processes (Internet 1).

The first two UNGEGN meetings were held in 1960 and 1966 in New York. They were followed by twenty-nine sessions. The first was held in 1967 in New York, and the latest in 2016 in Bangkok, Thailand. The thirtieth session in 2017 is being hosted by New York again (Internet 2). 


\subsection{Regional linguistic/geographic divisions}

UNGEGN is supported by regional linguistic/geographic divisions. Countries decide for themselves which division they wish to belong to; some belong to more than one division. Currently, there are twenty-four divisions that guide the work of UNGEGN during and between its sessions (Internet 3):

1. Africa Central Division: Angola, Burundi, Cameroon, the Central African Republic, Chad, Congo, the Democratic Republic of the Congo, Equatorial Guinea, Gabon, Rwanda, and São Tomé and Príncipe;

2. Africa East Division: Botswana, Burundi, Djibouti, Ethiopia, Kenya, Lesotho, Madagascar, Malawi, Mauritius, Mozambique, the Seychelles, Sudan, Swaziland, Tanzania, Uganda, Zambia, and Zimbabwe;

3. Africa South Division: Botswana, Lesotho, Madagascar, Malawi, Mozambique, Namibia, South Africa, Swaziland, Zambia, and Zimbabwe;

4. Africa West Division: Benin, Burkina Faso, Cape Verde, Côte d'Ivoire, Gambia, Ghana, Guinea, GuineaBissau, Liberia, Mali, Mauritania, Niger, Nigeria, Senegal, Sierra Leone, and Togo;

5. Arabic Division: Algeria, Bahrain, Comoros, Djibouti, Egypt, Iraq, Jordan, Kuwait, Lebanon, Libya, Morocco, Mauritania, Oman, Palestine, Qatar, Saudi Arabia, Somalia, Sudan, Syria, Tunisia, the United Arab Emirates, and Yemen;

6. Asia East Division (other than China): Japan, North Korea, and South Korea;

7. Asia South-East Division: Bhutan, Brunei, Cambodia, Indonesia, Laos, Malaysia, Myanmar, the Philippines, Singapore, Sri Lanka, Thailand, and Vietnam;

8. Asia South-West Division (other than Arabic): Afghanistan, Azerbaijan, Cyprus, Iran, Pakistan, Tajikistan, Turkey, and Turkmenistan;

9. Baltic Division: Estonia, Latvia, Lithuania, Poland, and Russia;

10. Celtic Division: France and Ireland;

11. China Division: China;

12. Dutch- and German-speaking Division: Austria, Belgium, Germany, the Netherlands, South Africa, Suriname, and Switzerland;

13. East Central and South-East Europe Division: Albania, Bosnia and Herzegovina, Bulgaria, Croatia, Cyprus, Czech Republic, Georgia, Greece, Hungary, Macedonia, Montenegro, Poland, Serbia, Slovakia, Slovenia, Turkey, and Ukraine;

14. Eastern Europe, Northern and Central Asia Division: Armenia, Azerbaijan, Belarus, Bulgaria, Georgia, Kazakhstan, Kyrgyzstan, Russian Federation, Tajikistan, Ukraine, and Uzbekistan;

15. East Mediterranean Division (other than Arabic): Cyprus and Israel;

16. French-Speaking Division: Algeria, Belgium, Bulgaria, Burkina Faso, Cameroon, Canada, Congo, Côte d'Ivoire, the Democratic Republic of the Congo, France, Guinea, Lebanon, Madagascar, Morocco, Niger, Romania, Senegal, Spain, Switzerland, Togo, and Tunisia;

17. India Division: Bangladesh, Bhutan, India, Nepal, and Pakistan;

18. Latin America Division: Argentina, Bolivia, Brazil, Chile, Colombia, Costa Rica, Cuba, the Dominican Republic, Ecuador, El Salvador, Guatemala, Haiti, Honduras, Mexico, Nicaragua, Panama, Paraguay, Peru, Spain, Suriname, Uruguay, and Venezuela;

19. Norden Division: Denmark (including Greenland and the Faroe Islands), Finland, Iceland, Norway, and Sweden;

20. Pacific South-West Division: Australia, Fiji, Nauru, New Zealand, Papua New Guinea, Samoa, the Solomon Islands, Timor-Leste, Tonga, and Vanuatu;

21. Portuguese-speaking Division: Angola, Brazil, Cape Verde, Guinea-Bissau, Mozambique, Portugal, São Tomé and Príncipe, and Timor-Leste;

22. Romano-Hellenic Division: Andorra, Belgium, Canada, Cyprus, France, Greece, Holy See, Italy, Luxembourg, Moldova, Monaco, Portugal, Romania, Spain, Switzerland, and Turkey;

23. United Kingdom Division: Guyana, Jamaica, New Zealand, South Africa, and the United Kingdom of Great Britain and Northern Ireland;

24. USA/Canada Division: Canada and the United States.

\subsection{East Central and South-East Europe linguistic/geographical division}

Slovenia is part of the East Central and South-East Division, which has seventeen members. The first session of the division was held in 1971 in Prague and the last one in 2015 in Ljubljana (Internet 4). Slovenia 
has presided over this section twice: the first time from January 22nd, 1998 to September $4^{\text {th }}, 2002$, and again from August 9th, 2012 to August $16^{\text {th }}, 2017$. The division mainly deals with the transliteration and transcription of geographical names from non-Roman scripts into Roman and with exonyms, which most of the participants addressed at the last meeting in Ljubljana.

\section{Geographical names in the world}

Place names have always been studied for diverse reasons and by several disciplines, especially by linguistics (Taylor 1998). Until recently, they were approached predominantly as »windows into the past «. Research in this area has been very productive and continues to be advanced by a number of researchers (Conedera et al. 2007; Kathrein 2009).

Recently, however, one can observe an important development in place name research across the social sciences, namely in anthropology and geography, which represents a break with the past. The new approaches emphasize the contemporaneity of place names (while not ignoring their historical roots) and study them in relation to the political situation and contestations of place, landscape, and identity.

Initial propositions of these new perspectives on place names have been put forth by Tuan (1977; 1990; $1991)$ within geography and Basso $(1988 ; 1996)$ in cultural anthropology. Both argue that naming is a very fundamental social and existential practice whereby people establish their relationship with the space they occupy and use. Tuan showed that human spatial perception is structured by language, and that place names play an important role in the perception and representation of the environment. Basso specified place naming as a way of writing or making history and relating to the world at a very fundamental, existential level, with place names closely tied to identity.

However, there is yet another dimension to place names: power. People are not, and never have been, in equal positions to name places, neither individually nor collectively. Place names may constitute cultural heritage and may be important for establishing and reproducing social identities, but they are also loaded with emotions, alternative interpretations, and contested histories-and, as such, they are not politically innocent. As Tuan shows, they must be understood in the context of current power relations, which (strive to) reproduce themselves through various material and non-material practices, one of them being place names. It is precisely this focus on the politics of place naming that "critical toponymy « has developed (Rose-Redwood, Alderman and Azaryahu 2010). Critical toponymy is a lively current in contemporary place name research that critically examines the relationship between toponymy and power. It analyzes the ways in which political regimes and movements use place names to claim territories, erase linguistic traces of original populations, gain political legitimacy, delegitimize other political forces, naturalize certain versions of history, and silence dissent.

UNGEGN, which was described above, focuses on the standardization of geographical names. In principle it is a political body, although it is composed of an interdisciplinary set of scholars with a predominance of linguists, geographers, and cartographers. However, there are two additional global forums concerned with research on geographical names: the International Council of Onomastic Sciences (ICOS) and the joint commission on toponymy of the International Cartographic Association (ICA) and International Geographical Union (IGU). ICOS was founded in 1949 and deals with all kinds of proper names; that is, not only place names, but also names of persons and animals. However, place names play a growing role in ICOS activities, as documented by its triannual congresses and by its journal Onoma, which has been published since 1950. The Joint ICA/IGU Commission on Toponymy was founded in 2012 by the two global umbrella organizations of cartography and geography as a joint venture. Its initiation was also strongly supported by UNGEGN because the necessity was felt that the rather formal and political discussions in UNGEGN had to be supplemented by cartographic and geographical research. As a matter of fact, many UNGEGN experts are also active in this commission. The commission holds toponymy sessions as part of ICA and IGU congresses and conferences, and it also holds separate symposia on specific topics such as place-name changes and publishes proceedings. The themes of critical toponymy and the symbolic power of place names are very much in the foreground of its current activities. 


\section{Geographical names in Slovenia}

Slovenian geographers have been dealing with geographical names for a long time. Already in the sixteenth century, Slovenian Baron Sigismund von Herberstein (1486-1566) from Vipava dealt with exonyms, transcription and transliteration. He contributed to knowledge about Russia, and his work Rerum Moscoviticarum commentarii (Notes on Muscovite Affairs) contained the first detailed maps of the European part of Russia, entitled Moscovia (Kladnik 2012).

Much later, the watershed year of 1848 awakened and strengthened the consciousness of European ethnic groups, including the Slovenians. Atlant, the first world atlas in Slovenian (1869-1877), prepared by Matej Cigale (1819-1889), is important for Slovenian exonyms. Cigale Slovenianized over four thousand foreign geographical names (Urbanc et al. 2006; Kladnik et al. 2006). For Slovenian endonyms, Peter Kosler's (1824-1879) map of Slovenian ethnic territory at a scale of about 1:600,000 (1853) is important. He collected over five thousand Slovenian names (Kladnik 2012).

However, real accelerated and systematic development in the field of geographical names and their standardization came about after Slovenia's independence in 1991.

Since 1990, the Commission for the Standardization of Geographical Names of the Government of the Republic of Slovenia has been responsible for geographical names in Slovenia. Since 1995, it has been headquartered at the Anton Melik Geographical Institute of the Research Centre of the Slovenian Academy of Sciences and Arts. It consists primarily of experts in geography, linguistics, cartography, and history as well as representatives of relevant ministries.

In 2001, the commission prepared the Concise gazetteer of Slovenia (Perko 2001) with standardized geographical names on the 1:1,000,000 National Map of the Republic of Slovenia. To date, the commission has also standardized the Slovenian names of countries and their main appertaining territories (Kladnik et al. 2013), as well as nearly five thousand geographical names in Slovenia recorded on the 1:250,000 National Map of the Republic of Slovenia (Furlan et al. 2008).

Slovenian geographers have also contributed to scholarly discussions on critical toponymy. Examples of problematic treatment of geographical names, such as the historical evolution of names for the Bay of Piran, have been presented and thoroughly discussed (Kladnik 2008; Kladnik, Pipan and Gašperič 2014). This geographic name is important for building the social identities and it is filled with emotions because it lies in the area of a border dispute between Slovenia and Croatia.

\section{Articles in this special issue}

For this special thematic issue of the journal Acta geographica Slovenica, some of the participants in the last session of the East Central and South-East Europe linguistic/geographical division prepared four research articles, which are briefly presented in this introductory chapter.

The first two articles deal with exonyms. The article »A comparison of Croatian and Slovenian exonyms" (Kladnik et al. 2017) compares exonyms in the two languages. Croatian and Slovenian are very closely related South Slavic languages, but during their historical development they came under the influence of various other languages and various language policies determined by the broader framework of Hungary and Austria.

A quick overview of exonyms in both languages reveals that many of them are completely identical, some differ in details only, and only a few differ significantly; for example, Vienna (German Wien, Slovenian Dunaj, Croatian Beč), Venice (Italian Venezia, Slovenian Benetke, Croatian Venecija), or the Rhine (Romansh Rein, German Rhein, French Rhin, Dutch Rijn, Slovenian Ren, Croatian Rajna).

The two Slovenian and two Croatian authors tested the existing Slovenian typology of exonymization and its applicability in Croatian. This led them to improve the methodology by adding a missing category and to look for suitable examples of exonymization for all categories in both languages-which could be identical, could differ, or could appear in only one of the two languages. The final result is a new typology of exonymization with twelve levels of Slovenianization and Croatization from the smallest to greatest degree of adaptation.

The article "Slovenian exonyms in North America " (Perko and Kladnik 2017) notes that the number of Slovenian exonyms around the world decreases with distance from Slovenia. However, this applies less so to North America, where their density is twice as high as in South and Central America, which is associated 
with the above-average global role of North America in the last century and the emigration of Slovenians in past centuries.

This quite remote part of the world was presented to Slovenians relatively early through Frederic Baraga (1797-1868), a Slovenian Catholic missionary to the United States and a grammarian of Native American languages (Kladnik 2012).

The authors prepared a spreadsheet with 3,819 exonyms and thirty-five thematic fields. For the analysis of Slovenian exonyms in North America, they considered all of the names on three maps (divided into three sections) at a scale of 1:50,000,000 that fall within Canada and the United States (excluding Greenland and Central America) and without names of undersea features (all three maps are included in the article). The final number of these names is 204, and the final number of names from the list of 3,819 names without undersea features is 3,316 .

The analysis shows that in North America marine hydronyms (21.1\%) are the most numerous semantic type of exonyms, and completely translated names (77.9\%) are the most numerous Slovenianized type of exonyms. Among the original languages of exonyms, English completely prevails (97.1\%).

The most commonly used Slovenian exonyms from North America in Slovenian texts are the names of countries and their administrative units. The next most commonly used Slovenian exonyms are Dolina smrti »Death Valley«, Veliki kanjon »Grand Canyon«, Niagarski slapovi »Niagara Falls«, Skalno gorovje »Rocky Mountains«, and Aleuti »Aleutian Islands« (Perko and Kladnik 2017).

The third article, »Microtoponyms as an important part of Slovenian cultural heritage " (Škofic 2017), deals with oeconyms and other microtoponyms in Slovenia. Geographical names are important part of the cultural heritage of every nation. For small nations with a small but diverse territory like Slovenia (Ciglic and Perko 2013; Perko, Ciglič and Hrvatin 2017; Perko, Hrvatin and Ciglič 2015), microtoponyms are a particularly important component of the cultural heritage. The author stresses that they often reflect the geomorphological, historical, biological, geological, and social characteristics of a country, as well as the historical development of the spoken language. People use microtoponyms to designate the space where they live and work, and to make orientation in it easier.

The author presents a methodology for data collection and documentation of microtoponyms in the Upper Carniolan dialect of Slovenian based on video and audio recordings. The author states that linguistic analysis and its consideration of the dialect characteristics of toponyms can help in reconstructing their naming motivation and origin.

A very interesting category of microtoponyms are oeconyms, also known as house names and farm names. The author determines oeconym as a toponym that denotes an occupied or unoccupied house with a street number in a settlement, a farm with or without land, farm outbuildings (e.g., grain mills, sawmills), or communal village buildings (e.g., a church, rectory, school, inn, or fire station). Oeconyms remain connected to houses and estates even after the original owners move on and may remain unchanged for centuries.

The author says that many of these names are of Slavic origin, but many of them are loanwords from various contact languages, mostly German and Italian. Oeconyms and other microtoponyms are mainly one-word toponyms. More complex structured toponyms are quite rare (Škofic 2017).

The first three articles link history with the present; however, the last article is based more on the current situation and the future. Its title is a question: "Does Google serve as a model for using place names? « (Gercsák and Mikesy 2017). Printed maps, names indexes, legends, and several traditional tools that have helped in correctly understanding and interpreting place names seem to be disappearing from everyday use. The authors say that, in the world of computers, most map users are turning to online methods or mobile applications when they need spatial information.

The article examines the reliability of geographical names published on various internet platforms in the case of Hungarian place names. The most common mistakes found by the authors are missing diacritics, use of historical names without modern equivalents, use of names never approved, false linking of exonyms, and automatic translations of place names.

With regard to automatic translations, the authors say that strange names typically appear on web pages for Austrian and Slovenian territories. The following are some examples:

- The Austrian name Leitersdorf im Raabtal »Leitersdorf in the Rába Valley« near Feldbach was replaced by the name Rábakarmestere, which means »conductor of the Rába River«;

- Instead of the Austrian name Raabau »Rába River floodplain « one finds Rábaakadálymentes, which roughly means »obstacle-free Rába River«; 
- The Hungarian exonym for the southern Austrian settlement of Ehrenhausen (literally, »home of honesty«) is Ellöbecsület, which means »living honesty«;

- The name Radkersburg/Gornja Radgona (literally, »Radger Castle«) on the Austrian-Slovenian border is translated as Kerékerösitövár, which means "wheel-strengthening castle«; and

- The nearby village of Podgrad (literally, »below the castle«) on the Slovenian side is Keréknekfel, which means »up on the wheel .

The author says that the birth of false geographic names in large numbers in the popular media represents a considerable linguistic, cultural, informational, and economic challenge, partly because the false names are mixed with relevant data. They believe it is very important for the responsible geographical name authorities and the developers of online maps to cooperate and monitor the use of place names on the internet (Gercsák and Mikesy 2017).

\section{Conclusion}

Geographical names are such an important feature of geographical space that they may be seen as one of the foundations of every civilization. Through them, the land is »filled « with meanings. Spatially related identities can evolve only after a place has been given a name. Because geographical space is also a place of contact between different cultures, the same area may have different or overlapping geographical names. Through such contacts, the need for discussion and standardization of geographical names is quickly established. In international relations, standardization only became possible in the framework of the United Nations after the Second World War, when some common ground was established. Research on geographical names is based on official gazetteers or official lists of geographical names that have been established and mostly deal with the problems of exonyms and endonyms, as well as social aspects of geographical names, such as power relations. They refer to the positional power of societies and nations, can be used as referential power to attract people and build loyalty, and are related to expert power (Morgan 1986).

Geographical names may thus be seen as one of the last nation-building aspects of geography.

This special issue offers some insight into the discussion on the important area of geographical names. This introductory article briefly presents the main terms (geographical name or toponym, endonym, exonym, transliteration, transcription, and standardized geographical name) and then discusses the formal framework of their standardization within UNGEGN. The modern approaches and main research globally and in Slovenia are then discussed, followed by four examples. The examples comprise a discussion of Croatian and Slovenian exonyms, Slovenian exonyms in North America, microtoponyms as a part of Slovenian cultural heritage, and Google as a model for using place names. We believe that this special issue will contribute to scholarly discourse and perhaps even foster a new discussion.

\section{References}

Basso, K. H. 1988: Speaking with names: language and landscape among the Western Apache. Cultural Anthropology 3-2.

Basso, K. H. 1996. Wisdom sits in places. Landscape and language among the Western Apache. Albuquerque.

Ciglič, R., Perko, D. 2013: Europe’s landscape hotspots. Acta geographica Slovenica 53-1. DOI: http://dx.doi.org/ 10.3986/AGS53106

Conedera, M., Vassere, S., Neff, C., Meurer, M., Krebs, P. 2007. Using toponymy to reconstruct past land use: a case study of »Brusada (Burn) in southern Switzerland. Journal of Historical Geography 33. DOI: http://dx.doi.org/10.1016/j.jhg.2006.11.002

Furlan, M., Gložančev, A., Kladnik, D., Perko, D., Šivic-Dular, A. 2008: Standardized Slovene geographical names. Gazetter of the National general map of the Republic of Slovenia at the scale 1:250,000. Ljubljana.

Gercsák, G., Gábor, M. 2017: Does Google serve as a model for using place names?. Acta geographica Slovenica 57-1. DOI: http://dx.doi.org/10.3986/AGS.4668

Internet 1: http://unstats.un.org/unsd/geoinfo/ungegn (15.11.2016).

Internet 2: http://unstats.un.org/unsd/geoinfo/ungegn/sessions.html (15.11.2016).

Internet 3: http://unstats.un.org/unsd/geoinfo/ungegn/divisions.html (15.11.2016). 
Internet 4: http://ecseed.zrc-sazu.si (15.11.2016).

Jordan, P. 2016: Place names as an expression of human relations to space. ICOS 2014. Names and their environment. Proceedings of the $25^{\text {th }}$ International Congress of Onomastic Sciences, 25.-29. August 2014. Glasgow.

Kladnik, D. 2008: Bay of piran or bay of Savudrija? An example of problematic treatment of geographical names. Acta geographica Slovenica 48-1. Ljubljana. DOI: http://dx.doi.org/10.3986.AGS48103

Kladnik, D. 2012: Slovenian geography and geographical names. Geografski vestnik 84-1.

Kladnik, D., Ciglič, R., Hrvatin, M., Perko, D., Repolusk, P., Volk, M. 2013: Slovenski eksonimi. Geografija Slovenije 24. Ljubljana.

Kladnik, D., Perko, D. 2013: Slovenska imena držav. Geografija Slovenije 25. Ljubljana.

Kladnik, D., Pipan, P., Gašperič, P. 2014: Poimenovanja Piranskega zaliva. Geografija Slovenije 27. Ljubljana.

Kladnik, D., Crljenko, I., Čilaš Šimpraga, A., Geršič, M. 2017: A comparison of Croatian and Slovenian exonyms. Acta geographica Slovenica 57-1. DOI: http://dx.doi.org/10.3986/AGS.4653

Kladnik, D., Urbanc, M., Fridl, J., Orožen Adamič, M., Perko, D. 2006: Ein Kartenfund in Slowenien und sein Faksimilendruck: Ein wichtiges Ereignis für Sloweniens und Österreichs historische Geographie. Mitteilungen der Österreichischen Geographischen Gesellschaft 148.

Kathrein, Y. 2009: Onomastic research within a project on historical mining sites. The research program "HiMAT « in Austrian Tyrol working paper 4. Session of the United Nations Group of Experts on Geographical Names (UNGEGN) in Nairobi 5.-12. 5.2009.

Morgan, G. 1986: Images of Organization. London

Perko, D. 2001: Concise gazetteer of Slovenia. Ljubljana.

Perko, D., Ciglič, R., Hrvatin, M. 2017: Determination of landscape hotspots of Slovenia. Acta geographica Slovenica 57-1. DOI: http://dx.doi.org/10.3986/AGS. 4618

Perko, D., Hrvatin M., Ciglič, R. 2015: A methodology for natural landscape typification of Slovenia. Acta geographica Slovenica 55-2. DOI: http://dx.doi.org/10.3986/AGS.1938

Perko, D., Kladnik, D. 2017: Slovenian exonyms in North America. Acta geographica Slovenica 57-1. DOI: http://dx.doi.org/10.3986/AGS.4777

Rose-Redwood, R., Alderman, D., Azaryahu, M. 2010: Geographies of toponymic inscription: new directions in critical place-name studies. Progress in Human Geography 34-4.

Škofic, J. 2017: Microtoponyms as an important part of Slovenian cultural heritage. Acta geographica Slovenica 57-1. DOI: http://dx.doi.org/10.3986/AGS.4670

Taylor, S. (ed.) 1998: The uses of place names. Edinburgh.

Tuan, Y.-F. 1977: Space and place: The perspective of experience. Minneapolis.

Tuan, Y-F. 1990 (1974): Topophilia. A study of environmental perception, attitudes, and values. New York.

Tuan, Y.-F. 1991: Language and the making of place: A narrative-descriptive approach. Annals of the Association of American Geographers 81.

Urbanc, M., Fridl, J., Kladnik, D., Perko, D. 2006: Atlant and Slovene national consciousness in the second half of the $19^{\text {th }}$ century. Acta geographica Slovenica 46-2. DOI: http://dx.doi.org/10.3986/AGS46204 